\title{
Scale microchemistry as a tool to investigate the origin of wild and farmed Salmo salar
}

\author{
E. A. Adey ${ }^{1,3, *}$, K. D. Black ${ }^{1}$, T. Sawyer ${ }^{1}$, T. M. Shimmield ${ }^{1}$, C. N. Trueman ${ }^{2}$ \\ ${ }^{1}$ Scottish Association for Marine Science, Dunstaffnage Marine Laboratory, Oban PA34 1QA, UK \\ ${ }^{2}$ School of Ocean and Earth Science, National Oceanography Centre, University of Southampton, European Way, \\ Southampton SO14 3ZH, UK \\ ${ }^{3}$ Present address: Birmingham City University, Perry Barr, Birmingham B42 2SU, UK
}

\begin{abstract}
Atlantic salmon Salmo salar are extensively farmed throughout their natural range, and unintentional interactions between farmed fish and wild populations have been implicated in the decline of wild salmon. The trace element composition of salmon scales distinguishes wild from farmed fish, and potentially provides a rapid and cheap method to assess the extent of escaped farmed fish within a wild population. Scale samples from wild and farmed fish from sites throughout Scotland were analysed for a large number of trace elements using inductively coupled plasma mass spectrometry (ICP-MS). Discriminant function analysis of the resulting data classified wild and farmed fish with $98 \%$ accuracy. Mn is identified as the element contributing most to the dissimilarity between wild and farmed fish, with scales from farmed fish yielding significantly higher concentrations of Mn. Scale chemistry also differed between farms. 87\% of samples taken from six farm sites around the west coast of Scotland were correctly classified to their farm of origin. Scale chemistry provides a powerful tool to determine the origin of S. salar, despite the potential for post-depositional change in elemental concentrations of scale bioapatite.
\end{abstract}

KEY WORDS: Fish $\cdot$ Microchemistry $\cdot$ Trace element $\cdot$ Food forensics $\cdot$ Origin $\cdot$ Ecology $\cdot$ Aquaculture

\section{INTRODUCTION}

Populations of wild Atlantic salmon Salmo salar declined rapidly towards the end of the twentieth century (ICES 2006). At the same time aquaculture industries expanded considerably, increasing the numbers of farmed fish potentially able to escape into the wild. For example, the Scottish Government reported 154466 escaped salmon from 12 farms in 2007 (www. scotland.gov.uk/Resource/Doc/1062/0055496.pdf), and after storms in Scotland in January 2005, more than 600000 Atlantic salmon were reported to have escaped (http://news.bbc.co.uk/2/hi/scotland/4287407. stm; accessed 27 August 2009). Escaped farmed salmon can successfully interbreed and alter the genetic structure of wild populations (Skaala et al. 1990, Volpe et al. 2001), with 'genetic erosion' having seri- ous consequences on the survival ability of species (Kapuscinski \& Brister 2001). Gross (1998) suggested that when farmed fish escape into the wild, they should be treated as exotic alien species and recognised as a new biological entity, Salmo domesticus (Gross 1998). Farmed salmon have cardiac and swimming performances similar to wild salmon, giving them the capacity to compete with wild salmon in native waters (Dunmall \& Schreer 2003). It has also been demonstrated that competition between escaped farmed salmon and wild populations resulted in reduced wild smolt production, which has the potential to create an extinction vortex in vulnerable populations of wild salmon (McGinnity et al. 2003). Assessing the extent of farm-origin salmon within wild populations is critical in determining the influence of farm escapes on wild populations. Identifying the farm (or 
region) of origin of any escaped fish would help identify aquaculture operations in need of improved husbandry practices.

Various techniques have been used to distinguish between wild and farmed salmon, such as: body morphology and shape, chemical marking (Behrens Yamada et al. 1979, Behrens Yamada \& Mulligan 1987), scale patterns (Lear \& Misra 1978, Lund \& Hansen 1991, Hiilivirta et al. 1998), genetics (Beacham et al. 1995) and pigments (distinguishing between natural and artificial astaxanthin) (Turujman et al. 1997). However, the efficacy of these techniques reduces with increasing time post-escape. Further methods of identifying wild and farmed fish include tagging and fin clipping, although these techniques can be difficult to perform on small fish (Behrens Yamada \& Mulligan 1987) and are labour intensive (Ennevor \& Beames 1993). Furthermore, recapture rates of fish in tagging studies can be very low (Rien \& Beamesderfer 1994) and provide no information on the history of a fish prior to tagging (Veinott et al. 1999).

The elemental and isotopic composition of biominerals (including bones, teeth, scales and otoliths), are increasingly used to track movements in individual fish (e.g. Kalish 1990, Fowler et al. 1995, Secor et al. 1995), identify regional differences between stock populations (e.g. Thresher et al. 1994, Severin et al. 1995, Campana et al. 1997) and assess connectivity between nursery grounds and adult stocks (e.g. Elsdon \& Gillanders 2003). These techniques exploit the relationship between the trace metal content of a biomineral and that of the ambient water during biomineral construction; thus regional differences in water composition are reflected in biominerals and therefore potentially reflect the region of origin. Tissues such as otoliths and scales grow incrementally, and may provide a record of the location of the fish over its whole life; spatially resolved analyses could provide information about location throughout ontogeny.

At present, few studies have attempted to use scale chemistry to distinguish between wild and farmed salmon, or to differentiate amongst farm populations. Gausen \& Berg (1988) analysed the Sr content in scales and vertebrae of hatchery-reared and wild Salmo salar, concluding that $\mathrm{Sr}$ in scales cannot distinguish between wild and hatchery-reared smolts in most localities (although significant differences were found in Sr levels in smolts from 2 hatcheries). A more recent study using high resolution laser ablation inductively coupled plasma mass spectrometry (LA-ICP-MS) to ablate sections of a scale from the pre-smolt stage, found that 2 farmed populations differed chemically from one wild and one cultivated stock, although the 2 farmed populations were only partially delineated from one another (Flem et al. 2005).
Veinott \& Porter (2005) suggest that a database of elemental fingerprints of otoliths from different salmon farms may allow identification of the origin of escapee fish from aquaculture operations (e.g. Gillanders \& Joyce 2005). Use of scale tissue has advantages over using otoliths; they are removed non-lethally and therefore enable multiple sampling throughout the life of a fish, and sample handling and preparation is relatively simple when analysing scales. Fish scales are composed of bioapatite with a relatively poorly constrained crystal lattice. The bioapatite lattice may accommodate a wider range of trace elements at higher concentrations than otolith aragonite (e.g. Wells et al. 2000a,b). However, scales are not considered to be metabolically inactive like otoliths, raising concern over elemental stability after deposition (e.g. Wells et al. 2000a). While relatively few controlled experimental studies have tested the post-depositional stability of elemental compositions in scale bioapatite, uncertainties have ensured that scale microchemistry has received relatively little attention. Spatially resolved elemental analyses demonstrate that when fish move rapidly across strong chemical gradients (e.g. migration from freshwater to seawater in salmon), the scale chemistry preserves a similarly abrupt change in elemental composition (Fig. 1), indicating that while some postdepositional chemical exchange may occur, it is not sufficient to overprint large differences in elemental composition related to the ambient water. The aims of the present study are to determine whether scale chemistry provides a reliable method of distinguishing between wild and farmed fish, as well as between farmed populations, and also to identify the elements that contribute to successful discriminations.

\section{MATERIALS AND METHODS}

General methodology. Analyses of biominerals, such as in fish scales, is notoriously difficult, requiring extreme care in cleaning and preparation techniques, followed by careful standardisation of measurement protocols (see Table 1). At present no standard analytical protocol exists for determining trace metals in fish scales (e.g. Coutant \& Chen 1993, Pender \& Griffin 1996, Wells et al. 2000a, 2003), hence the need to undertake experimentation to determine optimal analytical procedures. Full details of these experiments are provided in Adey (2007) and are summarised below.

Data collection and analyses. Scale samples collected specifically for this study were removed using plastic knives and forceps, whereas some archived scale samples also used in this study had been removed using a metal knife. All samples were taken 
from the left hand side of the fish approximately 1 to 3 rows above the lateral line (Shearer 1992) and stored in paper envelopes prior to use. Investigations suggest that if scale samples are cleaned prior to analysis, removal of the scales by metallic implements does not significantly affect the trace element concentrations found to be essential for discriminating amongst origin (Adey 2007).

Wild fish scale samples used in the present study were collected opportunistically, and were a mixture of archived samples collected and stored by fisheries biologists between 1987 to 2004, and samples collected by fisheries biologists and anglers in 2004. The archived samples were collected from the following rivers: Gruinard $(\mathrm{n}=15,1995)$, Laxdale $(\mathrm{n}=16,2000)$,

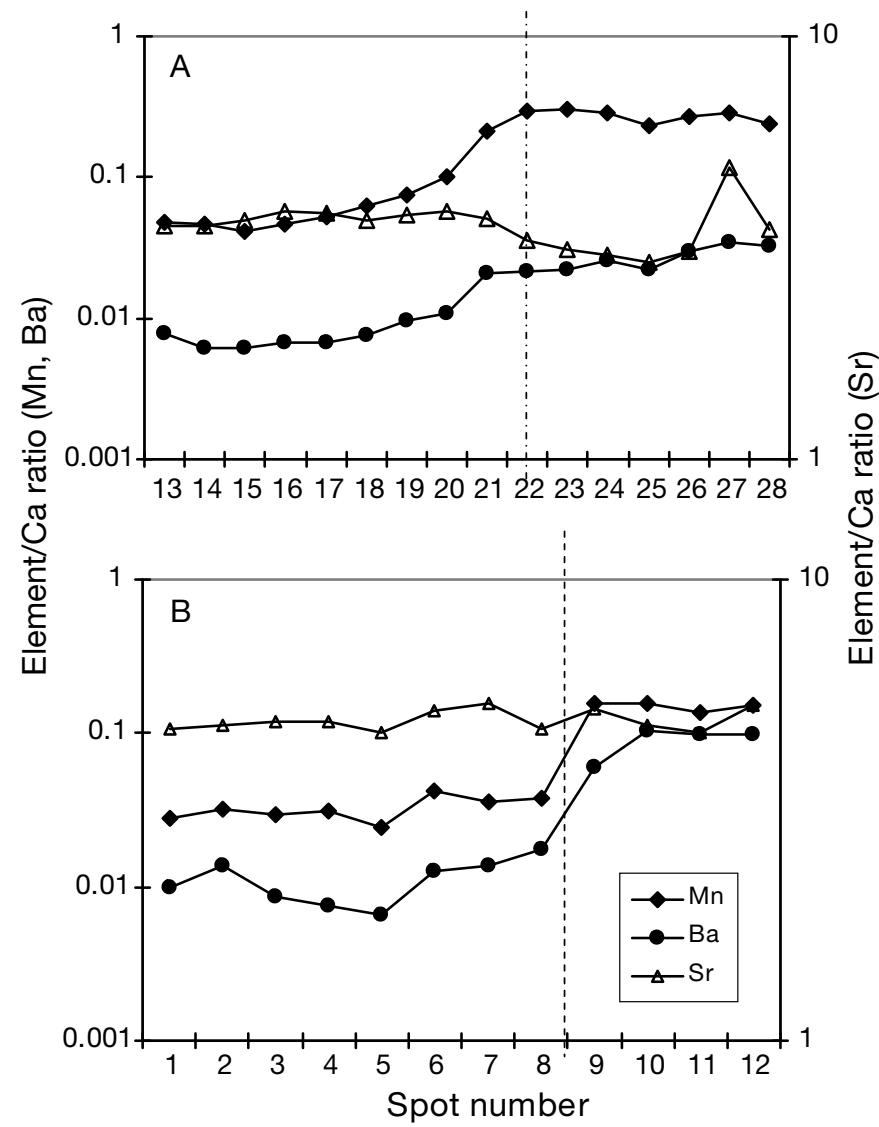

Fig. 1. Salmo salar. Sr/Ca $\mathrm{Mn} / \mathrm{Ca}$ and $\mathrm{Ba} / \mathrm{Ca}$ ratios determined by laser ablation ICP-MS across fish scales from (A) River Esk and (B) Greenland Research Fishery. Spot number corresponds to laser shots, Spot 1 is located in the scale centre. Dashed line indicates the position of the 'smolt line' identified from scale reading. Individual laser shots are separated by ca. $70 \mu \mathrm{m}$. Note the abrupt reduction in $\mathrm{Ba} / \mathrm{Ca}$ and $\mathrm{Mn} / \mathrm{Ca}$ ratios associated with transition from freshwater to seawater, and stable elemental ratios characterising seawater and freshwater residency. In fish A, Sr/Ca ratios increase significantly on entry to seawater. Scales kindly donated by

A. Youngson (Fisheries Research Services, Pitlochry)
Spey (n = 111, 1991 and 1992) and Tay ( $\mathrm{n}=25,1987)$. In 2004, a total of 230 wild fish were sampled for scales, taken from a further 15 different rivers in Scotland: Almond ( $\mathrm{n}=5)$, Ayr $(\mathrm{n}=13)$, Blackwater $(\mathrm{n}=14)$, Conon $(\mathrm{n}=24)$, Dochart $(\mathrm{n}=15)$, Doon $(\mathrm{n}=11)$, Errochty ( $n=21)$, Garnock ( $n=8)$, Garry ( $n=7)$, Girvan $(\mathrm{n}=5)$, Inver $(\mathrm{n}=40)$, Lyon $(\mathrm{n}=7)$, Orchy $(\mathrm{n}=30)$, Stinchar ( $\mathrm{n}=4)$ and Tilt $(\mathrm{n}=26)$ (Fig. 2). These sites were selected to cover a wide range of rivers from different areas in Scotland, including the Outer Hebrides. The amount of time wild fish spent in the river prior to capture and scale removal was not known. Farmed fish scales used in this study were collected during 2004. A total of 172 farmed fish were sampled from 10 farms located on the west coast of Scotland: Ardgaddan ( $\mathrm{n}=$ 15), Ardmaddy $(\mathrm{n}=42)$, Badcall Bay $(\mathrm{n}=14)$, Gob a Bharra ( $\mathrm{n}=8)$, Geasgill $(\mathrm{n}=16)$, Glenan $(\mathrm{n}=15)$, Inch Kenneth $(\mathrm{n}=8)$, Meall Mhor $(\mathrm{n}=18)$, Portree $(\mathrm{n}=24)$ and Strondoir Bay $(\mathrm{n}=12)$ (Fig. 2). Farm sites were chosen to incorporate farms from a wide range of areas on the West coast of Scotland. Samples from Badcall Bay were taken from 3 different hatcheries, but were grouped together after preliminary analysis suggested there was very little difference between the stocks. Five farms from Loch Fyne were sampled; Ardgaddan, Glenan, Gob a Bharra, Meall Mhor and Strondoir Bay. All of the fish from Loch Fyne had been transferred into the Loch as smolts during September/October 2003, prior to originating from 4 hatchery sites. Scales from the Loch Fyne fish were removed before carcass quality experiments in August 2004, with fish having spent 11 mo in seawater (fish are normally harvested after 14 to 22 mo at sea). All of the other scale samples were taken from fish that were harvested for consumption (14 to $22 \mathrm{mo}$ at sea). Scale samples were taken from 11 fish suspected to have escaped from farms based on evidence of fin erosion. These samples originated from 4 different rivers; Awe $(n=2)$, Blackwater $(\mathrm{n}=2)$, Fyne $(\mathrm{n}=6)$ and Spey $(\mathrm{n}=1)$.

A number of scale cleaning methods were tested (Adey 2007), and the optimal cleaning method used on scales was found to follow methods described by Wells et al. (2000b). Cleaning experiments revealed that scales should not be cleaned using weak $\mathrm{HNO}_{3}$ (e.g. Gillanders 2001), because of reduced concentrations of trace metals in samples cleaned using this method (Adey 2007).

The optimal dissolution procedure and analytical conditions were assessed using 2 standard reference materials (NIST 120c Florida phosphate rock and NIST bone meal 1486) testing digestions in: $\mathrm{HNO}_{3}, \mathrm{HNO}_{3}$ and $\mathrm{HCl}, \mathrm{HNO}_{3}$ and $\mathrm{HF}$. A mean weight of $0.034 \mathrm{~g}$ of fish scales (exact number of scales varied dependent on sample availability) were weighed and digested in $2 \mathrm{ml}$ of Super Purity Acid (SpA) $\mathrm{HNO}_{3}$ (metallic impu- 
rities $<1 \mathrm{ng} \mathrm{g}^{-1}$, assay 67 to $69 \%$ ) at approximately $70^{\circ} \mathrm{C}$ until a near dry state was achieved, at which time an additional $0.5 \mathrm{ml}$ of $\mathrm{HNO}_{3}$ was added. Samples were covered with a Teflon watch glass, and heat was used for a minimum period of time ( 10 min) until the sample was completely dissolved. Samples were made up to $10 \mathrm{ml}$ using $18.2 \Omega$ reverse osmosis water.
To enable an accurate assessment of a range of trace elements with widely differing concentrations, samples were diluted twice with $5 \% \mathrm{HNO}_{3}$, one at approximately $1000 \times$ dilution, and one at approximately $5000 \times$ dilution. An internal standard (overall concentration $10 \mathrm{ng} \mathrm{g}^{-1}$ of In and $\mathrm{Bi}$ ) was added to each sample to account for instrumental changes. Samples were analysed using stan-

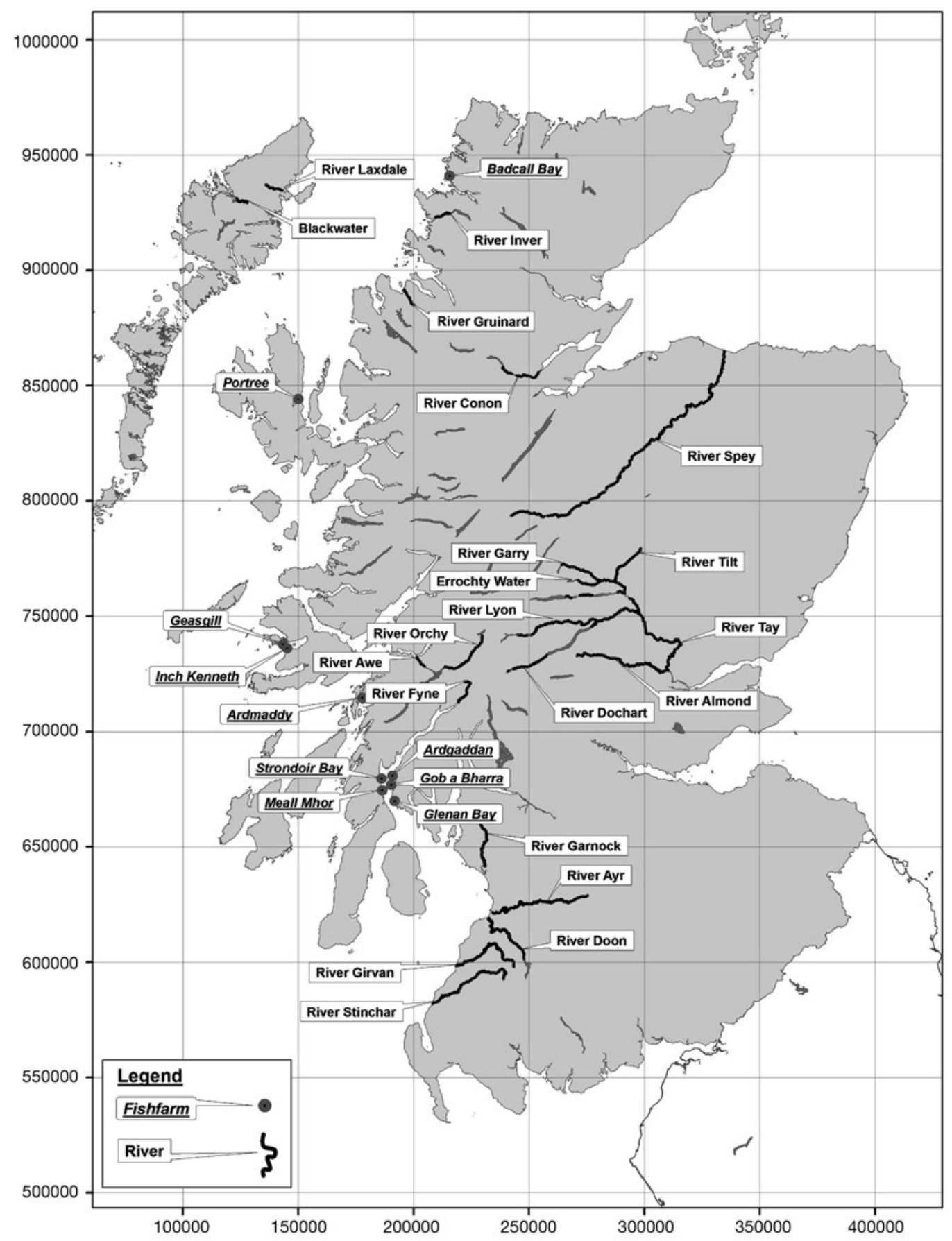

Fig. 2. Salmo salar. Map of Scotland showing the location where wild and farmed fish were sampled for scales. Map grid reference system uses Ordnance Survey coordinates 
Table 1. Quality control methods used to ensure adequacy of sample preparation and analysis

\begin{tabular}{|c|c|}
\hline $\begin{array}{l}\text { Standard reference materials (SRMs) } \\
\text { used ( } 2 \text { of each SRM per run) })^{\mathrm{a}}\end{array}$ & $\begin{array}{l}\text { NIST: } 1486 \text { bone meal } \\
\text { 120c Florida phosphate rock } \\
\text { IAEA } 407 \text { fish tissue }\end{array}$ \\
\hline Internal standards & $10 \mathrm{ng} \mathrm{g}^{-1} \mathrm{In}$ and $\mathrm{Bi}$ \\
\hline Detection limits & $\begin{array}{l}\text { Limit of detection }(\mathrm{LOD})=3 \times \mathrm{SD} \text { of } \\
\text { acid blanks }\end{array}$ \\
\hline Calibration ranges & $\begin{array}{l}1000 \times \text { dilution: } 0-10 \mathrm{ng} \mathrm{g}^{-1} \\
5000 \times \text { dilution: } 0-500 \mathrm{ng} \mathrm{g}^{-1}\end{array}$ \\
\hline Blank subtraction & $\begin{array}{l}5 \% \mathrm{HNO}_{3} \text { blank used for sample } \\
\text { correction }\end{array}$ \\
\hline Contamination monitoring & Process blank samples monitored \\
\hline
\end{tabular}

Element concentrations were not all normally distributed so data were $\log _{10}$ +1 transformed to provide a best fit to a normal distribution. Classical linear discriminant analysis was performed, and the total classification success was assessed using jackknifed classification matrices. The relative influence of each element on the total classification was assessed using stepwise classification statistics, and the proportion of variance explained by each element was assessed through canonical variate correlation coefficients. dard addition methods to minimise interferences. At $1000 \times$ dilution a $0-10 \mathrm{ng} \mathrm{g}^{-1}$ calibration range was used, and at $5000 \times$ dilution a $0-500 \mathrm{ng} \mathrm{g}^{-1}$ calibration range was used. Analyses were conducted on a VG PlasmaQuad 3 (Thermo) ICP-MS (with S-Option). Concentrations of 24 elements were measured; $\mathrm{V}, \mathrm{Cr}, \mathrm{Mn}, \mathrm{Ni}$, $\mathrm{Rb}, \mathrm{Ba}, \mathrm{U}, \mathrm{Li}, \mathrm{Co}, \mathrm{Cu}, \mathrm{Zr}, \mathrm{Mo}, \mathrm{Ag}, \mathrm{Cd}, \mathrm{Cs}, \mathrm{Ce}, \mathrm{Sm}, \mathrm{Pb}$ and Th were analysed using a dilution of $\sim 1000 \times$, and $\mathrm{Mn}$, $\mathrm{Cr}, \mathrm{Ni}, \mathrm{Mg}, \mathrm{Ti}, \mathrm{Fe}, \mathrm{Zn}, \mathrm{Sr}, \mathrm{Pb}, \mathrm{U}, \mathrm{V}, \mathrm{Cu}$ and $\mathrm{Ba}$ were analysed using a dilution of $\sim 5000 \times$. Mn, Ni, U, Cr, V, Pb, $\mathrm{Cu}$ and $\mathrm{Ba}$ were analysed at both dilutions to accommodate varying concentrations found in different samples, with results accepted when the analysed concentration fell within the calibration range. Processed blank samples were analysed alongside scale samples, and evidence of abnormal levels of contamination that were beyond background contamination levels led to a rejection of samples from the current study. Analyses were undertaken in random order, and results were blank subtracted to account for background metal contamination levels (Table 1 provides a summary of quality control methods used).

Statistical analyses. Univariate analyses were undertaken on all trace elements, apart from Ag and Th, which were frequently below the limits of detection (LOD). Fe, Mg and Ti were also excluded from data analyses due to the difficulty in measuring these elements by ICP-MS. LOD were calculated and used to exclude data. Anderson-Darling tests were used to test for normality, and transformations used where necessary. Parametric (ANOVA) or non-parametric (Kruskal-Wallis) tests and Tukey and Dunn tests for multiple comparisons were performed accordingly.

Multivariate analysis (MANOVA) was performed on a reduced element selection chosen to ensure that all samples contained element concentrations above detection limits. The reduced element list included: $\mathrm{Mn}$, $\mathrm{Ni}, \mathrm{Cu}, \mathrm{Ba}, \mathrm{Co}, \mathrm{V}, \mathrm{Sr}, \mathrm{Zn}, \mathrm{Cr}, \mathrm{Li}, \mathrm{Pb}$ and U. The grouping factor was either origin (wild, farm or farm escapee) or farm location.

\section{RESULTS}

\section{Distinguishing between wild and farm-origin salmon}

Concentrations of $\mathrm{Cr}, \mathrm{Ni}, \mathrm{Cu}, \mathrm{Pb}, \mathrm{Co}, \mathrm{Rb}, \mathrm{Zr}, \mathrm{Cd}, \mathrm{Cs}$ and $\mathrm{Ce}$ were higher $(\mathrm{p}<0.05)$ in scale samples taken from wild fish, and conversely, Mn, Li and Mo were found in higher concentrations in farmed fish $(\mathrm{p}<0.05)$.

Multivariate analysis demonstrates that the trace element composition of Salmo salar scales differ significantly between wild and farmed fish (Wilks' lambda test $\left.F_{12,556}=206.46, \mathrm{p}<0.0001\right)$. Jackknifed discriminant analysis successfully classified $98 \%$ of both farmed and wild fish. $\mathrm{Mn}, \mathrm{Li}, \mathrm{Ba}, \mathrm{Pb}, \mathrm{Cr}, \mathrm{Zn}, \mathrm{Ni}, \mathrm{U}$ and Co all contribute significantly to the classification ( $p$ to-remove $<0.05)$. A single discriminant function explained $100 \%$ of variation, and canonical variate correlation coefficients indicate that classification was overwhelmingly dominated by $\mathrm{Mn}(0.71)$, followed by $\mathrm{Li}$ (0.45), and to a lesser extent $\mathrm{Pb}(-0.23)$ and $\mathrm{Cr}$ $(-0.19)$. Graphical representations of the differences in scale composition between wild, farmed and farm escape fish are presented in Figs. 3 \& 4

Discriminant functions derived from analyses of samples of known origin (wild or farmed) were then used to classify 11 scale samples taken from wildcaught fish of suspected farm origin. Nine of these fish were identified as being of farmed origin; however 2 samples were classified as wild fish due to lower Mn concentrations (one from the river Blackwater and one from the Spey).

\section{Variation of scale composition between farms}

ANOVA identified that concentrations of $\mathrm{Cr}, \mathrm{Mn}, \mathrm{Ni}$, $\mathrm{Cu}, \mathrm{Ba}, \mathrm{Pb}, \mathrm{U}, \mathrm{Li}, \mathrm{Co}, \mathrm{Rb}, \mathrm{Zr}, \mathrm{Mo}, \mathrm{Cd}, \mathrm{Cs}, \mathrm{Ce}, \mathrm{Sm}, \mathrm{V}, \mathrm{Zn}$ and $\mathrm{Sr}$ in scale samples differ significantly $(\mathrm{p}<0.05)$ between the 10 farms sampled. 


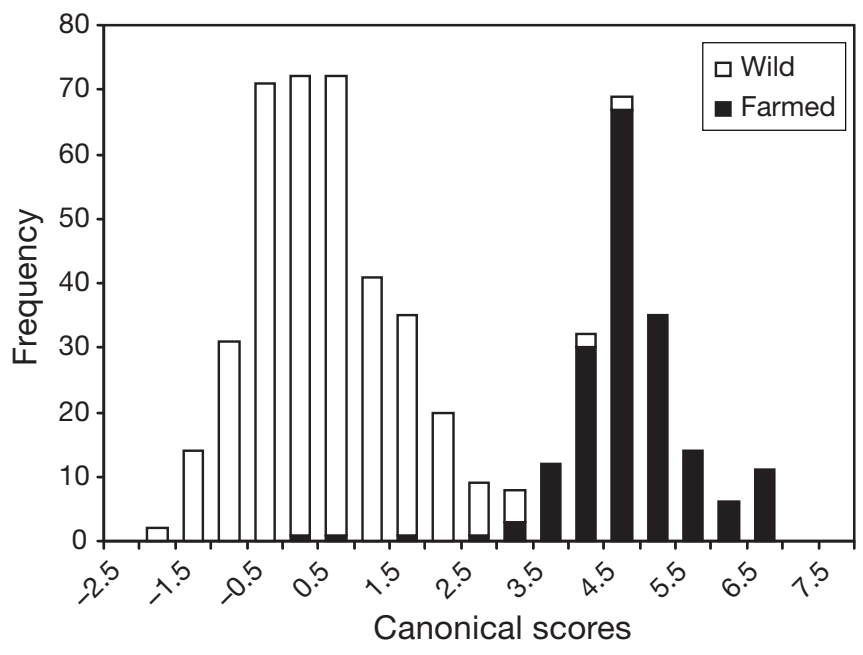

Fig. 3. Salmo salar. Frequency histogram of canonical scores from the single discriminant function accounting for $100 \%$ of the variance in trace element composition between wild $(n=397)$ and farm $(n=172)$ origin scales

MANOVA indicates that the farm of origin significantly influences scale chemistry (Wilks' lambda test; $\left.F_{108,1111}=11.28, \mathrm{p}<0.0001\right)$. Scale samples from Badcall Bay yielded the lowest median (and mean) concentrations of $\mathrm{Mn}, \mathrm{Ni}, \mathrm{Ba}, \mathrm{Co}, \mathrm{Cd}, \mathrm{Cs}$ and $\mathrm{Zn}$ compared to other farms. The highest median (and mean) concentrations of $\mathrm{Sr}, \mathrm{Cu}, \mathrm{Ce}, \mathrm{Sm}$ and $\mathrm{Cs}$ were found in scales taken from the farm at Inch Kenneth. Interestingly, both the lowest and highest median concentrations of Cr were found in scales taken from fish of different farm origin within Loch Fyne.

$\mathrm{Ba}, \mathrm{Ni}, \mathrm{Pb}, \mathrm{Mn}, \mathrm{Co}, \mathrm{Zn}, \mathrm{Cr}, \mathrm{Li}, \mathrm{U}$ and $\mathrm{Sr}$ all contributed significantly (p-to-remove $<0.05$ ) to the discriminant function model, with the first 3 discriminant functions explaining $80 \%$ of total variance. Jackknifed discriminant analysis successfully identified $76 \%$ of the 172 farmed fish to their known farm of origin. The degree of classification success differed between farms: Ardgaddan (67\%), Ardmaddy (98\%), Badcall Bay (93\%), Geasgill (81\%), Glenan (80\%), Gob a Bharra $(88 \%)$, Inch Kenneth $(25 \%)$, Meall Mhor $(61 \%)$, Portree $(75 \%)$ and Strondoir Bay (58\%). Canonical variate correlation coefficients identified $\mathrm{Ba}, \mathrm{Zn}, \mathrm{Cu}, \mathrm{Mn}, \mathrm{Ni}$ and $\mathrm{Zn}$ as the most important predictor elements for distinguishing between farms. Details of element loadings for the first 3 discriminant functions are provided in Table 2 .

Results were re-analysed combining the 5 farm sites within Loch Fyne (Ardgaddan, Glenan, Gob a Bharra, Meall Mhor and Strondoir Bay) into a single site 'Loch Fyne', and the 2 closely situated sites from the Isle of Mull
(Geasgill and Inch Kenneth) into a single site 'Mull'. U and Sr no longer contributed significantly to the classification model, and jackknifed classification success improved to $85 \%$ overall. Classification success for individual farms varied; Loch Fyne (93\%), Ardmaddy (96\%), Badcall Bay (93\%), Mull (69\%) and Portree (50\%). Zn, Li, Mn, Ni and Pb contributed most to the discrimination between farms based on canonical variate correlation coefficients (full details in Table 3). A graphical representation of the discrimination between farms is shown in Fig. 5.

Location of farms within Loch Fyne strongly influences scale chemistry (Wilks' lambda test $F_{48,202}=6.62$, $\mathrm{p}<0.0001$ ), with results of the jackknifed analysis successfully classifying $73 \%$ of fish from Ardgaddan, $67 \%$ from Glenan, $75 \%$ from Gob a Bharra, $83 \%$ from Meall Mhor and $58 \%$ from Strondoir Bay, with an overall classification rate of $72 \%$. Co, $\mathrm{Ba}, \mathrm{Ni}$ and $\mathrm{Sr}$ contributed most to the discrimination between farms based on canonical variate correlation coefficients.

\section{DISCUSSION}

\section{Wild and farmed salmon}

The origin of Salmo salar (both farmed vs. wild origin, and specific farm identity), significantly influences trace element composition of scale apatite determined by solution-based ICP-MS analyses (Fig. 3). Despite the wide range of environmental conditions they

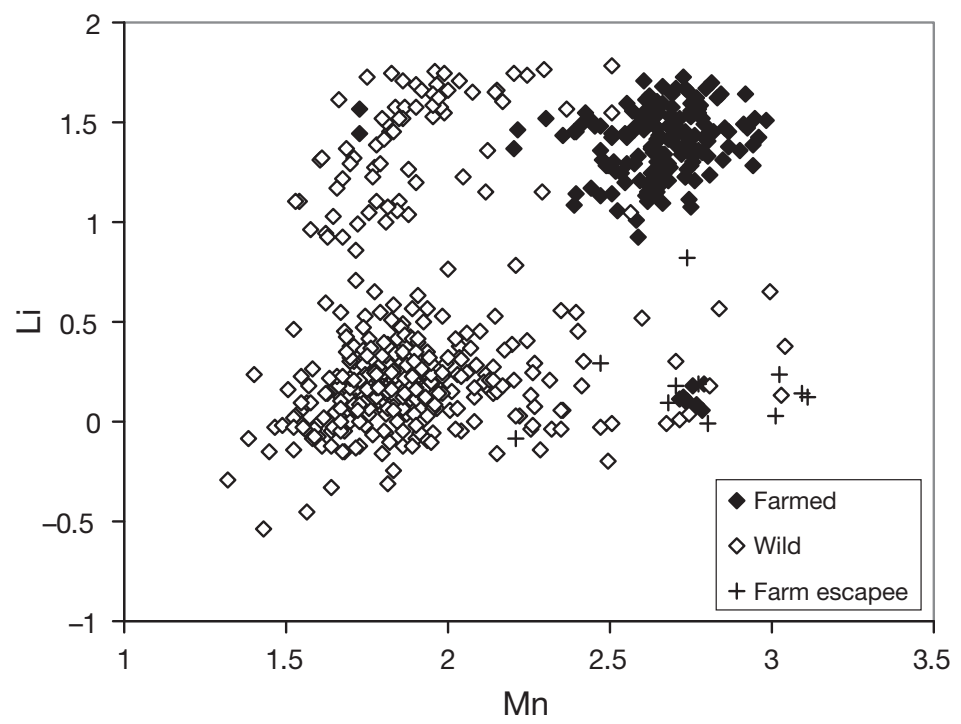

Fig. 4. Salmo salar. Scatter plot showing $\log +1$ normalised Mn and Li concentrations in farmed $(n=172)$, wild $(n=397)$ and farm escapee $(\mathrm{n}=11)$ fish. Wild fish with Li scores $>0.8$ are from rivers Conon $(100 \%$ of Conon samples), Inver (90\% of Inver samples) and Orchy (40\% of Orchy samples). Farmed fish with Li scores $<0.5$ all derive from the Portree farm site (30\% of Portree samples) 
Table 2. Canonical variate correlation coefficients for the first 3 discriminant functions (explaining $80 \%$ of total variance) modelling the influence of farm location on scale chemistry. All elements contribute significantly to the classification model

\begin{tabular}{|lrrr|}
\hline & \multicolumn{3}{c|}{ Discriminant functions } \\
& 1 & \multicolumn{1}{c|}{3} \\
\hline $\mathrm{Ba}$ & 0.582 & 0.043 & -0.420 \\
$\mathrm{Zn}$ & 0.475 & 0.009 & 0.010 \\
$\mathrm{Cu}$ & 0.249 & -0.173 & 0.473 \\
$\mathrm{Mn}$ & 0.225 & 0.455 & -2.900 \\
$\mathrm{Li}$ & 0.189 & -0.456 & 0.331 \\
$\mathrm{Co}$ & 0.056 & 0.269 & 0.552 \\
$\mathrm{Ni}$ & 0.031 & 0.553 & 0.650 \\
$\mathrm{~Pb}$ & -0.610 & 0.073 & 0.141 \\
$\mathrm{Sr}$ & -0.680 & -0.019 & -0.007 \\
$\mathrm{U}$ & -0.730 & 0.107 & 0.132 \\
$\mathrm{Cr}$ & -0.090 & -0.135 & 0.349 \\
\hline
\end{tabular}

Table 3. Canonical variate correlation coefficients for the first 3 discriminant functions (explaining $94 \%$ of total variance) modeling the influence of grouped farm location on scale chemistry. All elements contribute significantly to the classification model

\begin{tabular}{|lrrr|}
\hline & \multicolumn{3}{c|}{ Discriminant functions } \\
& 1 & 2 & \multicolumn{1}{c|}{3} \\
\hline $\mathrm{Zn}$ & 0.500 & 0.004 & 0.072 \\
$\mathrm{Ba}$ & 0.496 & 0.004 & -0.014 \\
$\mathrm{Li}$ & 0.217 & 0.620 & 0.272 \\
$\mathrm{Mn}$ & 0.280 & -0.462 & -0.014 \\
$\mathrm{Cu}$ & 0.271 & 0.276 & 0.557 \\
$\mathrm{Ni}$ & 0.020 & -0.308 & 0.531 \\
$\mathrm{Co}$ & 0.029 & -0.110 & 0.265 \\
$\mathrm{~Pb}$ & -0.100 & -0.020 & 0.379 \\
$\mathrm{Cr}$ & -0.133 & 0.226 & 0.176 \\
$\mathrm{Sr}$ & -0.092 & -0.047 & 0.051 \\
\hline
\end{tabular}

would have experienced, $98 \%$ of fish tested in the study were successfully classified as either farmed or wild on the basis of scale chemistry. In comparison to other techniques used to discriminate between farmand wild-origin fish, the classification success of scale chemistry was similar to those achieved by using scale characteristics (Hiilivirta et al. 1998) and microsatellite analysis (Skaala et al. 2004). Scale chemistry was also consistent with morphological assessments of wild caught fish suspected to have escaped from farms, demonstrating the potential practical use of this method. A small proportion of fish morphologically identified as 'wild' were found to have high Mn levels ( 20 'wild' fish had Mn levels over $20 \mathrm{ng} \mathrm{g}^{-1}$ and 15 were over $30 \mathrm{ng} \mathrm{g}^{-1}$ ) potentially suggesting an unsuspected farm-escape origin for these fish (Fig. 4).

Veinott \& Porter (2005) hypothesized that a database of otolith chemistries from aquaculture operations might help identify the origin of escapees. The rela-

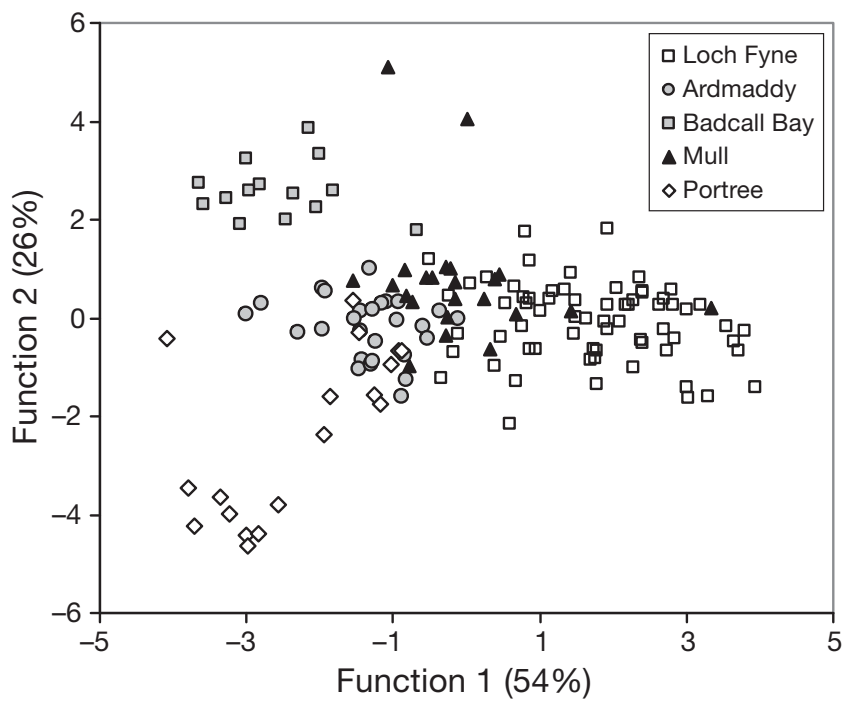

Fig. 5. Salmo salar. Canonical scores plot of the first 2 discriminant functions classifying scales to farm of origin. Total jacknifed classification success is $85 \%$. Samples from Loch Fyne ( $\mathrm{n}=67)$, Ardmaddy $(\mathrm{n}=27)$ and Badcall Bay $(\mathrm{n}=14)$ are all classified with $>90 \%$ accuracy, whereas samples from Mull $(\mathrm{n}=23)$ and Portree $(\mathrm{n}=18)$ are less successfully discriminated

tively high degree of variation in scale chemistry found between farms (Fig. 5) may also enable investigation of both the farm of origin of fish identified as escaped, and survivorship patterns of fish following release. Success in identifying escaped fish and farm of origin is likely to depend on the time period elapsed since escape.

Fish from 5 farms within Loch Fyne (a relatively small body of water) were discriminated with $72 \%$ accuracy based on elemental chemistry. It appears that whilst regional location has some influence on scale composition, it is not the only factor influencing the trace element composition of scales. Numerous other factors may contribute to the scale chemistry of farm fish, including: bedrock geology, salinity variations, particle concentration and flux, nutrient loading, water mass mixing and anthropogenic inputs.

Fish scales from the Badcall Bay farm had the lowest median or mean concentrations of $\mathrm{Mn}, \mathrm{Ni}, \mathrm{Ba}, \mathrm{Co}, \mathrm{Cd}$, $\mathrm{Cs}$ and $\mathrm{Zn}$ compared to samples from other fish farms. Stocking densities at Badcall Bay farm are lower than required (15 $\mathrm{kg} \mathrm{m}^{-3}$ compared to the standard $20 \mathrm{~kg}$ $\mathrm{m}^{-3}$ ), and no antifouling treatments are used on cages (www.lochduart.com/swimming \%20against \% 20the\% 20tide.htm). It is plausible that low concentrations of $\mathrm{Ni}, \mathrm{Co}, \mathrm{Cd}, \mathrm{Cs}$ and $\mathrm{Zn}$ found in scale samples of fish from Badcall Bay reflect differences in husbandry practices used between aquaculture operators, as these elements can have anthropogenic sources (de Vos et al. 2006). 
Manganese is the single element that differs most widely and consistently between the scales of farmed and wild fish, with higher Mn concentrations in farmed fish. Elevated Mn concentrations have also previously been reported in the juvenile portions of scales taken from adult Norwegian farm-origin fish (Flem et al. 2005). Three possible explanations exist for the enrichment of $\mathrm{Mn}$ in the scales of farmed fish: (1) water chemistry, (2) diet and (3) physiology.

(1) Water chemistry. Mn concentrations are typically enhanced in coastal waters compared to open waters (Bruland 1983, Thorrold et al. 1997, Hamer et al. 2006), reflecting low solubility of $\mathrm{Mn}$ oxides and rapid removal of $\mathrm{Mn}$ from solution and/or suspension. Hamer et al. (2006) found significantly elevated Mn concentrations near the margins of otoliths of sparidae (Pagrus auratus), correlating with collection from coastal water sites, and reflecting a pattern of migration between coastal and oceanic waters. However, it is unlikely that the enhanced Mn concentrations found in the scales of farmed fish in the present study reflect proximity to the coast, concentrations of Ba and Sr vary with salinity (e.g. Bagenal et al. 1973, Pender \& Griffin 1996, Courtemanche et al. 2006), but were not found to differ significantly between wild and farm-origin fish.

Increased Mn:Ca ratios in Atlantic croaker (Micropogonias undulates) otoliths have been linked to enhanced dissolved Mn concentrations caused by reducing conditions in hypoxic bottom waters (Thorrold \& Shuttleworth 2000). Hypoxic conditions are known to occur under fish farms (Pearson \& Black 2001), and it is possible that these conditions have contributed to elevated $\mathrm{Mn}$ concentrations in the water surrounding fish farms. In this case, Mn supplied by settling feed pellets and faeces is transferred to sediment in the vicinity of fish farms. Subsequent remobilisation of $\mathrm{Mn}$ into the water column results in increased concentrations of bioavailable $\mathrm{Mn}$, and thus elevated Mn concentrations in scales of farmed fish. The abundance and bioavailability of remobilised Mn would depend on environmental conditions such as water depth, refreshing rate and cycle, water chemistry, sediment redox state and stock density (e.g. Comans \& Van-Dijk 1988, Morris 1990, Turner et al. 1993, Owens \& Balls 1997), and the availability of Mn for incorporation into fish scales is therefore expected to vary between farm sites.

(2) Diet. Uptake of dietary trace elements into fish biominerals is not fully understood. Otolith-based studies report conflicting findings (e.g. Limburg 1995, Gallahar \& Kingsford 1996, Kennedy et al. 2000, Milton \& Chenery 2001, Walther \& Thorrold 2006). Mn is incorporated into fish biomineral from ambient water via the gills (Srivastava \& Agrawal 1983), although it is generally considered that it can be absorbed more easily through dietary uptake (Watanabe et al. 1997). Conversely, Mn concentrations in otoliths of black bream were not related to ambient water chemistry (Elsdon \& Gillanders 2003). Farmed fish feed is supplemented in $\mathrm{Mn}$ to improve growth and feed efficiency (Watanabe et al. 1997), hence dietary supplementation could account for high concentrations of $\mathrm{Mn}$ found in scales of farm-origin fish. Mn concentrations in commercial fish feed typically range from ca. 40 to $50 \mu \mathrm{g} \mathrm{g}^{-1}$ (Tacon \& Silva 1983), whereas Mn concentrations in fish muscle from marine waters are much lower, ranging from 0.1 to $1 \mu \mathrm{g} \mathrm{g}^{-1}$ (Türkmen et al. 2008). Mn concentrations in copepods are highly variable depending on source concentrations, but typically range from ca. 20 to $100 \mathrm{\mu g} \mathrm{g}^{-1}$ (Mackie \& Hunter 2005; Hsiao et al. 2006). Within vertebrates, a high proportion of the total body $\mathrm{Mn}$ is contained in bioapatite (e.g. bones and teeth), thus it is also possible that the relatively high Mn concentrations in scales of farm-origin fish reflect high levels of Mn present in their diet. However, many of the farms sampled in the current study use the same commercial fishmeal and, despite similarities in diet, concentrations of Mn in scales of fish vary significantly between farms, suggesting that diet is not the sole factor influencing Mn concentrations in scale apatite.

(3) Physiology. Mn is excreted by fish, and hence the variation seen in Mn levels amongst wild and farmorigin fish may reflect unknown physiological controls that impact on the ability of fish to accumulate $\mathrm{Mn}$ in their scales. This suggestion is supported as $\mathrm{Zn}$ and $\mathrm{Cu}$ are also supplemented in fishmeal, but unlike Mn, concentrations of $\mathrm{Zn}$ and $\mathrm{Cu}$ in scales are not significantly different between farm-origin and wild fish. This may also reflect differences in the bioavailability of supplemented metals and/or differences in the efficiency and mechanism of excretion of assimilated metals.

\section{Whole scales: freshwater or seawater?}

A key finding of the present study is the identification of significant differences in the trace element composition of the scales of fish collected from different seawater farms, but which originated from the same hatchery (fish raised at Gob a Bharra and Meall Mhor both came from a hatchery in Loch Ness, and some samples from Ardgaddan and all samples from Strondoir Bay came from a hatchery in Migdale). This suggests that differences found in the trace element composition of whole scales predominantly reflect uptake of trace elements during the post-smolt stage, with elemental signatures deposited during residence in freshwater hatcheries being masked.

Significant differences were found between the scale chemistry of farmed and farm escapee fish, sug- 
gesting elemental uptake continued in scales in the 'wild' phase of an escapee fish's life, either during continued scale deposition or during post-depositional mineralisation. Li concentrations in scales from suspected farm escapee fish were closer to the relatively low levels found in wild fish than those typically found in farmed fish ( $\mathrm{Li}$ median concentrations: wild = $0.17 \mu \mathrm{g} \mathrm{g}^{-1}$, farmed $=2.63 \mu \mathrm{g} \mathrm{g}^{-1}$ and farm escapee $=$ $0.14 \mu \mathrm{g} \mathrm{g}^{-1}$ ), but median Mn concentrations in farm escapee fish were higher than levels found in farmed fish. This suggests either that when farmed fish escape into the wild, Mn is relatively stable in fish scales compared to Li, or that the difference in Mn concentrations between farmed and wild fish is large enough to offset any post-depositional alteration of scale bioapatite composition.

It is likely that scale bioapatite continues to mineralise after deposition and that the trace element composition of scale bioapatite reflects this continuing mineralisation (Wells et al. 2000a,b, 2003). However, the extent of this post-depositional alteration may be small compared to pre-existing differences between cohorts (e.g. between wild and farmed fish, or between fish from areas with strongly contrasting water compositions). In such cases, scales may provide a valuable alternative to otoliths for microchemical investigation, with the advantages of non-lethal sampling and relative ease of sample handling. As with many studies involving tissue microchemistry, some prior knowledge of the likely elemental variation between sample groups is particularly helpful when designing an effective sampling and analytical strategy. Further work is needed on the stability of trace element composition of scale bioapatite, and on the potential of analysing specific portions of scales, either through physical dissection or spatially resolved sampling such as laser ablation (e.g. Flem et al. 2005).

\section{CONCLUSIONS}

Atlantic salmon Salmo salar are the most intensively farmed fish in high latitudes and the juxtaposition of intensive aquaculture cages with wild populations means that unintentional interaction between wild and farmed fish is inevitable. Hansen et al. (1999) recognise the importance of accounting for farmed components in catches of wild $S$. salar in assessing true populations of 'wild' fish. The present study has shown that solution-based fish scale chemistry provides a highly successful and relatively easy method to distinguish between farmed and wild S. salar, with high concentrations of $\mathrm{Mn}$ being the key marker that indicates farmed origin. Elevation of Mn in fish scales from farm populations is likely to be influenced predominantly by
Mn supplementation in commercial fish feed, with Mn cycling in water and sediment columns below salmon cages also having an impact. The difference in scale Mn concentrations between fish of wild and farmed origin are sufficiently large that recent escapees are likely to be identified on the basis of $\mathrm{Mn}$ alone, although the ability to identify farm escapees in the wild is likely to reduce over time as signals are masked by the uptake of elements after escape. In future studies, the use of LA-ICP-MS to determine Mn concentrations, alongside checks for the presence of a smolt line, may reduce the effects of signal dilution, with high Mn concentrations and the absence or reduction of a smolt line taken to indicate a fish of farmed origin. In such cases, the timing of escape may be reflected by a drop in $\mathrm{Mn}$ concentrations, and the farm or origin indicated by the wider elemental suite. Scale chemistry has a potential role in food forensics (e.g. tracking fraudulent labelling or marketing of salmon) and in conservation ecology. Further development of micro-sampling techniques may allow a database of the chemistry of farmed fish scales to help establish the farm or region of origin of escapee farmed fish that are caught in the wild.

Acknowledgements. This study was funded by UHI Millennium Institute. We are grateful for the assistance of: Alan Kettle White, Simon McKelvey, Alistair Duguid, Shona Marshall, Lorraine Hawkins, John Webb, Helen Bilsby, Loch Duart Ltd., Pan Fish (in particular Alex Adrian), Andy Walker and salmon anglers who assisted with scale collections. We also thank Susan McKinley and Tim Brand for assistance in the laboratory, and Steve Gontarek for helping to prepare the map used in this manuscript.

\section{LITERATURE CITED}

Adey EA (2007) Distinguishing populations of Atlantic salmon (Salmo salar) by elemental analysis of whole scales using Inductively coupled plasma-mass spectrometry. PhD dissertation, University of Aberdeen, Aberdeen

> Bagenal TB, MacKereth FJH, Heron J (1973) The distinction between brown trout and sea trout by the strontium content of their scales. J Fish Biol 5:555-557

Beacham TD, Withler RE, Wood CC (1995) Stock identification of sockeye salmon by means of minisatellite DNA variation. N Am J Fish Manag 15:249-265

Behrens Yamada S, Mulligan TJ (1987) Marking nonfeeding salmonid fry with dissolved strontium. Can J Fish Aquat Sci 44:1502-1506

Behrens Yamada S, Mulligan TJ, Fairchild SJ (1979) Strontium marking of hatchery-reared coho salmon (Oncorhynchus kisutch, Walbaum). J Fish Biol 14:267-275

Bruland KW (1983) Trace elements in seawater. In: Riley JP, Chester R (eds) Chemical oceanography. Academic Press, London, p 157-220

Campana SE, Jones CM, Gunther D, Tubrett M and others (1997) Comparison of accuracy, precision, and sensitivity in elemental assays of fish otoliths using the electron microprobe, proton-induced X-ray emission, and laser ablation inductively coupled plasma mass spectrometry. Can J Fish Aquat Sci 54:2068-2079 
Comans RNJ, Van-Dijk CPJ (1988) Role of complexation processes in cadmium mobilization during estuarine mixing. Nature 336:151-154

> Courtemanche DA, Whoriskey FG, Bujold V, Curry RA (2006) Assessing anadromy of brook char (Salvelinus fontinalis) using scale microchemistry. Can J Fish Aquat Sci 63: 995-1006

Coutant CC, Chen CH (1993) Strontium microstructure in scales of freshwater and estuarine striped bass (Morone saxatilis) detected by laser ablation mass spectrometry. Can J Fish Aquat Sci 50:1318-1323

de Vos W, Tarvainen T, Batista MJ, Pirc S and others (2006) Geochemical atlas of Europe. Part 2: Interpretation of geochemical maps, additional tables, figures, maps and related publications. Geological Survey of Finland, Espoo

> Dunmall KM, Schreer JF (2003) A comparison of the swimming and cardiac performance of farmed and wild Atlantic salmon, Salmo salar, before and after gamete stripping. Aquaculture 220:869-882

Elsdon TS, Gillanders BM (2003) Relationship between water and otolith elemental concentration in juvenile black bream Acanthopagrus butcheri. Mar Ecol Prog Ser 260:263-272

Ennevor BC, Beames RM (1993) Use of lanthanide elements to mass mark juvenile salmonids. Can J Fish Aquat Sci 50: 1039-1044

Flem B, Moen V, Grimstvedt A (2005) Trace element analysis of scales from four populations of Norwegian Atlantic salmon (Salmo salar L.) for stock identification using laser ablation inductively coupled plasma mass spectrometry. Appl Spectrosc 59:245-251

Fowler AJ, Campana SE, Jones CM, Thorrold SR (1995) Experimental assessment of the effect of temperature and salinity on elemental composition of otoliths using laser ablation ICP-MS. Can J Fish Aquat Sci 52:1431-1441

Gallahar NK, Kingsford MJ (1996) Factors influencing Sr/Ca ratios in otoliths of Girella elevata: an experimental investigation. J Appl Ichthyology 48:174-186

Gausen D, Berg OK (1988) Strontium levels in scales and vertabrae of wild and hatchery-reared Atlantic salmon, Salmo salar L., smolts. Aquacult Fish Manage 19:299-304

Gillanders BM (2001) Trace metals in four structures of fish and their use for estimates of stock structure. Fish Bull 99: 410-419

Gillanders BM, Joyce TC (2005) Distinguishing aquaculture and wild yellowtail kingfish via natural elemental signatures in otoliths. Mar Freshw Res 56:693-704

Gross MR (1998) One species with two biologies: Atlantic salmon (Salmo salar) in the wild and in aquaculture. Can J Fish Aquat Sci 55:131-144

Hamer PA, Jenkins GP, Coutin P (2006) Barium variation in Pagrus auratus (Sparidae) otoliths: A potential indicator of migration between an embayment and ocean waters in south-eastern Australia. Estuar Coast Shelf Sci 68: $686-702$

- Hansen LP, Jacobsen JA, Lund RA (1999) The incidence of escaped farmed Atlantic salmon, Salmo salar L., in the Faroese fishery and estimates of catches of wild salmon. ICES J Mar Sci 56:200-206

- Hiilivirta P, Ikonen E, Lappalainen J (1998) Comparison of two methods for distinguishing wild from hatchery-reared salmon (Salmo salar L.) in the Baltic Sea. ICES J Mar Sci 55:981-986

Hsiao HS, Fang TH, Hwang JS (2006) The bioaccumulation of trace metals in dominant copepod species of the northern Taiwan coast. Crustaceana 79:459-474

ICES (2006) Report of the working group on north Atlantic salmon. ACFM 23:4-13 April, ICES headquarters
Kalish JM (1990) Use of otolith microchemistry to distinguish the progeny of sympatric anadromous and nonanadromous salmonids. Fish Bull 88:657-666

Kapuscinski A, Brister DJ (2001) Genetic impacts of aquaculture. In: Black KD (ed) Environmental impacts of aquaculture. Sheffield Academic Press, Sheffield

Kennedy BP, Blum JD, Folt CL, Nislow KH (2000) Using natural strontium isotopic signatures as fish markers: methodology and application. Can J Fish Aquat Sci 57:2280-2292

Lear WH, Misra RK (1978) Clinal variation in scale characters of Atlantic salmon (Salmo salar) based on discriminant function analysis. J Fish Res Board Can 35:43-47

> Limburg KE (1995) Otolith strontium traces environmental history of subyearling American shad Alosa sapidissima. Mar Ecol Prog Ser 119:25-35

Lund RA, Hansen LP (1991) Identification of wild and reared Atlantic salmon, Salmo salar L., using scale characters. Aquacult Fish Manage 22:499-508

Mackie DS, Hunter KA (2005) The partitioning of zinc, manganese, cadmium and selenium within copepods in oceanic waters east of New Zealand. Mar Freshw Res 56: 95-100

> McGinnity P, Prodöhl P, Ferguson A, Hynes R and others (2003) Fitness reduction and potential extinction of wild populations of Atlantic salmon, Salmo salar, as a result of interactions with escaped farm salmon. Proc R Soc Lond B Biol Sci 270:2443-2450

Milton DA, Chenery SR (2001) Sources and uptake of trace metals in otoliths of juvenile barramundi. J Exp Mar Biol Ecol 264:47-65

Morris AW (1990) Kinetic and equilibrium approaches to estuarine chemistry. Sci Total Environ 97-98:253-266

Owens RE, Balls PW (1997) Dissolved trace metals in the Tay estuary. Estuar Coast Shelf Sci 44:421-434

Pearson TH, Black KD (2001) The environmental impacts of marine fish cage culture. In: Black KD (ed) Environmental impacts of aquaculture. Sheffield Academic Press, Sheffield

> Pender PJ, Griffin RK (1996) Habitat history of Barramundi Lates calcarifer in a north Australian river system based on barium levels in scales. Trans Am Fish Soc 125:679-689

Rien TA, Beamesderfer RC (1994) Accuracy and precision of white sturgeon age estimates from pectoral fin rays. Trans Am Fish Soc 123:255-265

Secor DH, Henderson-Arzapalo A, Piccoli PM (1995) Can otolith microchemistry chart patterns of migration and habitat utilization in anadromous fishes? J Exp Mar Biol Ecol 192:15-33

> Severin KP, Carroll J, Norcross BL (1995) Electron microprobe analysis of juvenile walleye pollock, Theragra chalcogramma, otoliths from Alaska: a pilot stock separation study. Environ Biol Fishes 43:269-283

Shearer WM (1992) Atlantic salmon scale reading guidelines. ICES Cooperative Research Report, Copenhagen 188:1-46

Skaala Ø, Dahle G, Jørstad KE, Nævdal G (1990) Interactions between natural and farmed fish populations: information from genetic markers. J Fish Biol 36:449-460

Skaala Ø, Hoyheim B, Glover KA, Dahle G (2004) Microsatellite analysis in domesticated and wild Atlantic salmon (Salmo salar L.): allelic diversity and identification of individuals. Aquaculture 240:131-143

Srivastava AK, Agrawal SJ (1983) Changes induced by manganese in fish testis. Experientia 39:1309-1310

> Tacon AGJ, Silva SS (1983) Mineral composition of some commercial fish feeds available in Europe. Aquaculture 31:11-20

Thorrold SR, Shuttleworth S (2000) In situ analysis of trace 
elements and isotope ratios in fish otoliths using laser ablation sector field inductively coupled plasma mass spectrometry. Can J Fish Aquat Sci 57:1232-1242

Thorrold SR, Jones CM, Campana SE (1997) Response of otolith microchemistry to environmental variations experienced by larval and juvenile Atlantic croaker (Micropogonias undulatus). Limnol Oceanogr 42:102-111

Thresher RE, Proctor CH, Gunn JS, Harrowfield IR (1994) An evaluation of electron-probe microanalysis of otoliths for stock delineation and identification of nursery areas in a southern temperate groundfish, Nemadactylus macropterus (Cheilodactylidae). Fish Bull 92:817-840

Türkmen M, Türkmen A, Tepe Y, Ateş A, Gökkuş K (2008) Determination of metal contaminants in sea foods from Maramara, Aegean and Mediterranean seas: twelve fish species. Food Chem 108:794-800

Turner A, Millward GE, Bale AJ, Morris AW (1993) Application of the kd concept to the study of trace metal removal and desorption during estuarine mixing. Estuar Coast Shelf Sci 36:1-13

Turujman SA, Warner WG, Wei RR, Albert RH (1997) Rapid liquid chromatographic method to distinguish wild salmon from aquacultured salmon fed sythetic astaxanthin. J AOAC Int 80:622-632

> Veinott G, Porter R (2005) Using otolith microchemistry to distinguish Atlantic salmon (Salmo salar) parr from different

Editorial responsibility: Hans Heinrich Janssen, Oldendorf/Luhe, Germany natal streams. Fish Res 71:349-355

Veinott G, Northcote T, Rosenau M, Evans RD (1999) Concentrations of strontium in the pectoral fin rays of the white sturgeon (Acipenser transmontanus) by laser ablation sampling-inductively coupled plasma-mass spectrometry as an indicator of marine migrations. Can J Fish Aquat Sci 56:1981-1990

Volpe JP, Glickman BW, Anholt BR (2001) Reproduction of aquaculture Atlantic salmon in a controlled stream channel on Vancouver Island, British Columbia. Trans Am Fish Soc 130:489-494

Walther BD, Thorrold SR (2006) Water, not food, contributes the majority of strontium and barium deposited in the otoliths of a marine fish. Mar Ecol Prog Ser 311:125-130

Watanabe T, Kiron V, Satoh S (1997) Trace elements in fish nutrition. Aquaculture 151:185-207

Wells BK, Bath GE, Thorrold SR, Jones CM (2000a) Incorporation of strontium, cadmium, and barium in juvenile spot (Leiostomus xanthurus) scales reflects chemistry. Can J Fish Aquat Sci 57:2122-2129

Wells BK, Thorrold SR, Jones CM (2000b) Geographic variation in trace element composition of juvenile weakfish scales. Trans Am Fish Soc 129:889-900

Wells BK, Thorrold SR, Jones CM (2003) Stability of elemental signatures in the scales of spawning weakfish, Cynoscion regalis. Can J Fish Aquat Sci 60:361-369

Submitted: June 26, 2008; Accepted: June 16, 2009

Proofs received from author(s): September 3, 2009 